WSRC-TR-2002-00115, Revision 0

\title{
Strategic Research: In-Tank Generation of Corrosion Inhibitors
}

\author{
D. T. Hobbs \\ D. P. Lambert
}

Westinghouse Savannah River Company

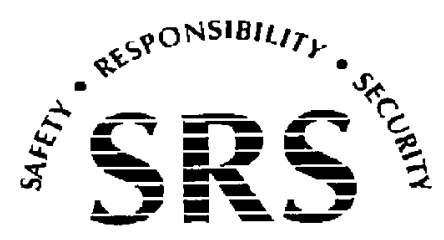


This document was prepared in conjunction with work accomplished under Contract No. DE-AC09-96SR18500 with the U. S. Department of Energy.

\section{DISCLAIMER}

This report was prepared as an account of work sponsored by an agency of the United States Government. Neither the United States Government nor any agency thereof, nor any of their employees, makes any warranty, express or implied, or assumes any legal liability or responsibility for the accuracy, completeness, or usefulness of any information, apparatus, product or process disclosed, or represents that its use would not infringe privately owned rights. Reference herein to any specific commercial product, process or service by trade name, trademark, manufacturer, or otherwise does not necessarily constitute or imply its endorsement, recommendation, or favoring by the United States Government or any agency thereof. The views and opinions of authors expressed herein do not necessarily state or reflect those of the United States Government or any agency thereof.

This report has been reproduced directly from the best available copy.

Available for sale to the public, in paper, from: U.S. Department of Commerce, National Technical Information Service, 5285 Port Royal Road, Springfield, VA 22161, phone: (800) 553-6847, fax: (703) 605-6900

email: orders@ntis.fedworld.gov

online ordering: http://www.ntis.gov/help/index.asp

Available electronically at http://www.osti.gov/bridge

Available for a processing fee to U.S. Department of Energy and its contractors, in paper, from: U.S. Department of Energy, Office of Scientific and Technical Information, P.O. Box 62, Oak Ridge, TN 37831-0062,

phone: (865)576-8401,

fax: (865)576-5728

email: $\underline{\text { reports@ adonis.osti.gov }}$ 
WSRC-TR-2002-00115, Revision 0

Keywords: Nitrate, Nitrite,

Hydroxide,

HLW,

Electrolytic

Retention: Permanent

\title{
Strategic Research: In-Tank Generation of Corrosion Inhibitors
}

\author{
D. T. Hobbs \\ D. P. Lambert
}

Publication Date: July 8, 2002

Westinghouse Savannah River Company

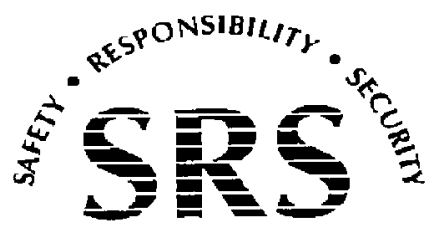

PREPARED FOR THE U.S. DEPARTMENT OF ENERGY UNDER CONTRACT NO. DE-AC09-96SR18500 
APPROVALS
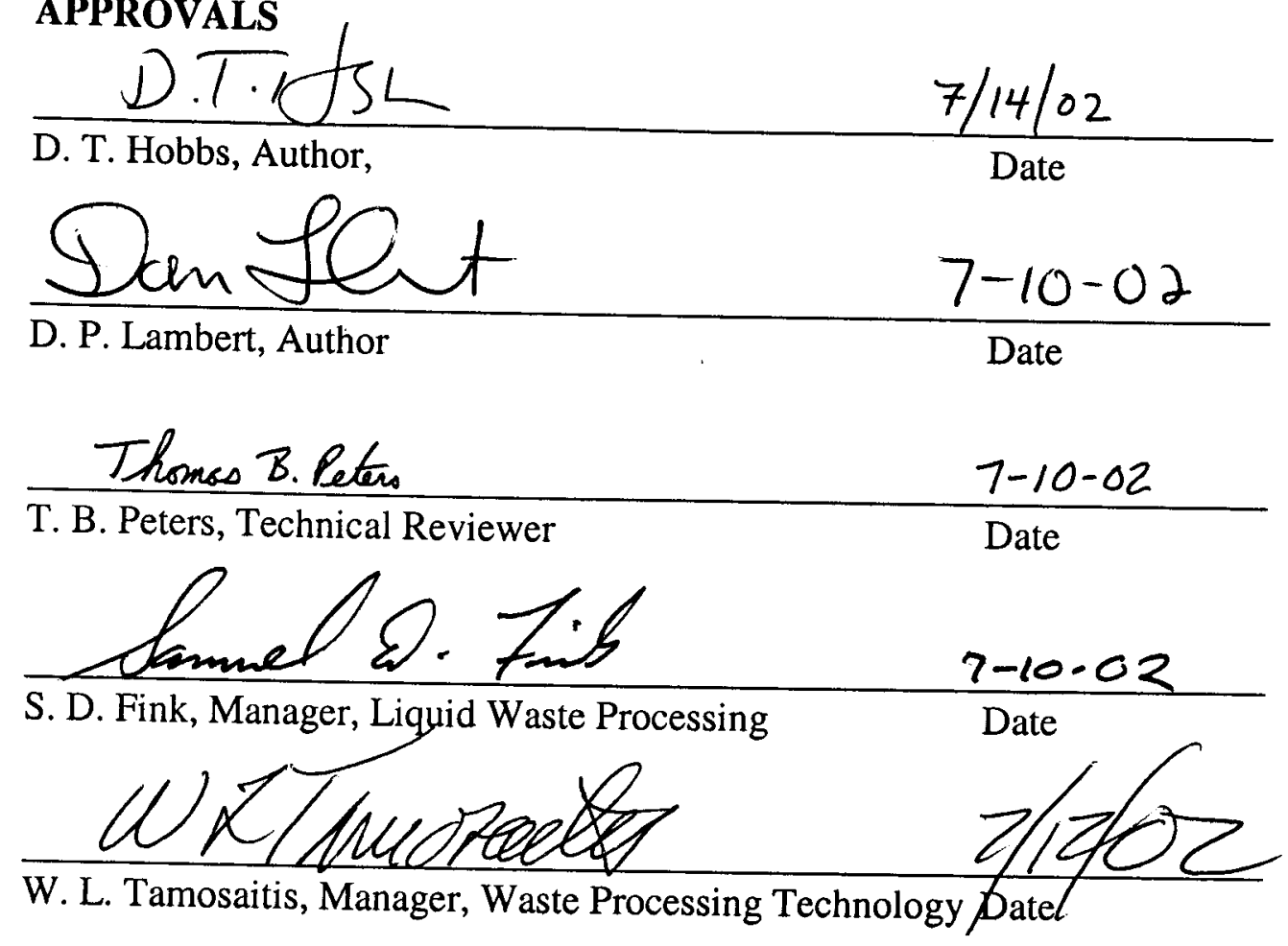

iv 


\begin{abstract}
Prevention of stress corrosion cracking and pitting corrosion in high-level waste (HLW) tanks requires the periodic addition of corrosion inhibitors, sodium hydroxide and sodium nitrite. These inhibitor ions can be generated electrochemically from the nitrate present in the waste. Thus, a continuously operated electrochemical reactor placed in the top of the tank could generate nitrite and hydroxide. In-tank generation would eliminate the need to continually add process chemicals resulting in cost savings associated with the procurement, pretreatment and disposal of these chemicals.

Experiments examined whether both nitrite and hydroxide could be generated simultaneously from a simple waste simulant in a single electrolytic cell. Results indicated that hydroxide, but not nitrite, formed at a rate that would be effective for intank generation. Nitrate reduction proceeded beyond the production of nitrite to produce other nitrogen-containing products. We recommend additional testing to identify an optimum cathode material for nitrite production. Alternatively, the in-tank generator may feature a divided cell configuration or dual electrochemical cells in which one cell generates hydroxide and the second cell generates nitrite.
\end{abstract}




\section{Introduction}

High-level waste (HLW) storage tanks at the Savannah River and Hanford sites feature carbon steel materials of construction. The alkaline wastes contain large amounts of corrosive species, chiefly nitrate with lesser amounts of sulfate and halides. Previous testing indicated two important corrosion mechanisms associated with the storage of the alkaline HLW, stress corrosion cracking and pitting corrosion. Hydroxide and nitrite ions are excellent inhibiting species for both corrosion mechanisms.

Currently HLW Operations at the Savannah River Site (SRS) periodically monitors the liquid phase compositions for corrosive and inhibiting species in each tank and adds inhibitors when necessary to maintain non-corrosive conditions. The hydroxide and nitrite ions are added as concentrated solutions of their respective sodium salts, sodium hydroxide and sodium nitrite. Consumption of the inhibitor solutions exceeds 100,000 gallons per year at the SRS. The addition of the corrosion inhibitors also impacts downstream waste disposal. For every gallon of caustic or sodium nitrite solution added to the HLW, an additional $4-6$ gallons of waste are produced that requires pretreatment in the salt processing facility and disposal in Saltstone or DWPF.

Previous testing of methods to destroy nitrates in alkaline waste solutions evaluated an electrochemical process. ${ }^{1}$ In this process, nitrate and nitrite ions reduce to nitrogen and ammonia at the cathode with the simultaneous production of hydroxide. Based on this previous testing, we proposed that an electrochemical process might to produce both nitrite and hydroxide from the nitrate present in waste solutions. The process would install - an electrochemical reactor within a HLW tank and produce corrosion inhibitors in situ to eliminate the addition of process chemicals. This report summarizes the initial results evaluating the feasibility of simultaneous production of nitrite and hydroxide in a single cell electrochemical reactor.

An electrolytic cell uses electric current to bring about a chemical change. A pair of electrodes immersed into an ionic solution and connected by an external metal conductor or electrode constitutes a typical electrochemical cell (Figure 1). The reaction at the surface of the electrode is a transfer of charge (electrons) to or from ions in solution. An electrode acting as a source of electrons is called an anode, an electrode acting as a sink of electrons is called an cathode. 


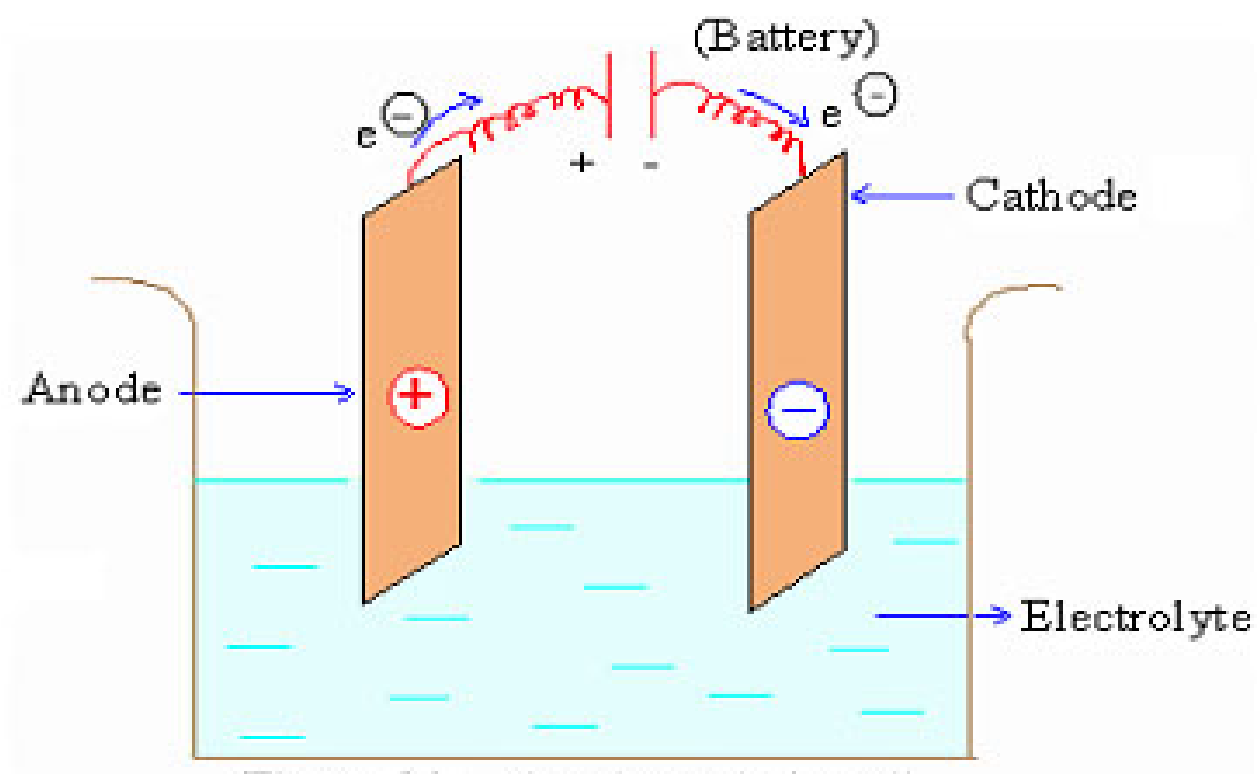

Figure 1 - Typical Electrolytic Cell

Electrolytic cells have a number or important commercial uses such as the production of sodium metal from salt, the production of aluminum from ore, and the production of sodium hydroxide and chlorine from a brine solution. Other electrochemical applications include the purification of water (i.e., electrodialysis), the destruction of hazardous components (e.g., nitrate and chromate) and the recovery of chemicals of value from waste solutions (e.g., silver and gold).

Nitrite and hydroxide ions form by the electrochemical reduction of nitrate ion at the cathode of an electrochemical cell (equation 1). The standard reduction potential $\left(\mathrm{E}_{\mathrm{o}}\right)$ for this reaction under alkaline conditions is $+0.01 \mathrm{~V}$ (vs. standard hydrogen electrode (SHE)). The relatively low standard reduction potential indicates that little energy is required to affect the conversion of nitrate into nitrite at standard conditions.

An anodic reaction is required to complete the electrochemical cell. Under alkaline conditions, hydroxide ion easily oxidizes to produce oxygen and water (equation 2). The $\mathrm{E}_{\mathrm{o}}$ for this reaction is $-0.401 \mathrm{~V}$ (vs. SHE). Equation 3 provides the overall net electrochemical cell reaction for the reduction of nitrate to nitrite utilizing the two halfcell reactions in equations 1 and 2 . Note that for the complete cell reaction, nitrite and oxygen are the only reaction products with no net production of hydroxide ion. For the balanced cell reaction, the potential is $-0.391 \mathrm{~V}$, which indicates that the reaction is not spontaneous and would require applying a potential of at least $0.391 \mathrm{~V}$ to affect the desired reaction. In practice, a higher potential would be required to account for inefficiencies that affect reactions at the electrode surface.

$$
\begin{array}{r}
\mathrm{NO}_{3}^{-}+\mathrm{H}_{2} \mathrm{O}+2 \mathrm{e}^{-}=\mathrm{NO}_{2}^{-}+2 \mathrm{OH}^{-} \\
4 \mathrm{OH}^{-}=2 \mathrm{O}_{2}+2 \mathrm{H}_{2} \mathrm{O}+4 \mathrm{e}^{-}
\end{array}
$$




$$
2 \mathrm{NO}_{3}^{-}=2 \mathrm{NO}_{2}^{-}+\mathrm{O}_{2}
$$

A net production of one hydroxide per nitrate can be achieved by further reducing the nitrite to nitrogen (equation 4). The $\mathrm{E}_{\mathrm{o}}$ for this reaction is $+0.406 \mathrm{~V}$ (vs. SHE). When combined with the hydroxide oxidation half-cell reaction, there is a net production of one mole of hydroxide formed per mole of nitrate consumed (equation 5).

$$
\begin{array}{r}
2 \mathrm{NO}_{2}^{-}+4 \mathrm{H}_{2} \mathrm{O}+6 \mathrm{e}^{-}=\mathrm{N}_{2}+8 \mathrm{OH}^{-} \\
4 \mathrm{NO}_{3}^{-}+2 \mathrm{H}_{2} \mathrm{O}=2 \mathrm{~N}_{2}+4 \mathrm{OH}^{-}+5 \mathrm{O}_{2}
\end{array}
$$

To produce nitrite and hydroxide simultaneously, conditions must be found such that nitrogen production reaction (equation 4) is slow relative to nitrite production (equation 3). This will result in an increase in the steady-state concentration of nitrite in the waste solution. Previous testing indicated that as nitrate concentrations decrease, nitrite concentrations increase and hydroxide concentrations increase when simulated and actual radioactive waste solution pass through an electrochemical reactor. ${ }^{2,3,4}$ In this testing, we attempted to destroy all of the nitrate and nitrite. Thus, we did not attempt to identify optimum conditions that would produce both nitrite and hydroxide.

\section{Experimental}

Initial testing examined whether simultaneous production of nitrite and hydroxide occur in high yield in an undivided cell configuration. The experimental setup included a 600 $\mathrm{mL}$ feed vessel (working volume $500 \mathrm{~mL}$ ), a $10 \mathrm{~cm}^{2}$ electrolytic cell manufactured by Electrocell $\mathrm{AB}$ and a Scilog Expert recirculation pump. The electrical power came from by a Hewlett-Packard 6281A DC Power supply. We checked the voltage and current using a Fluke 25 Multimeter. Figure 2 is a photograph of the testing equipment. 


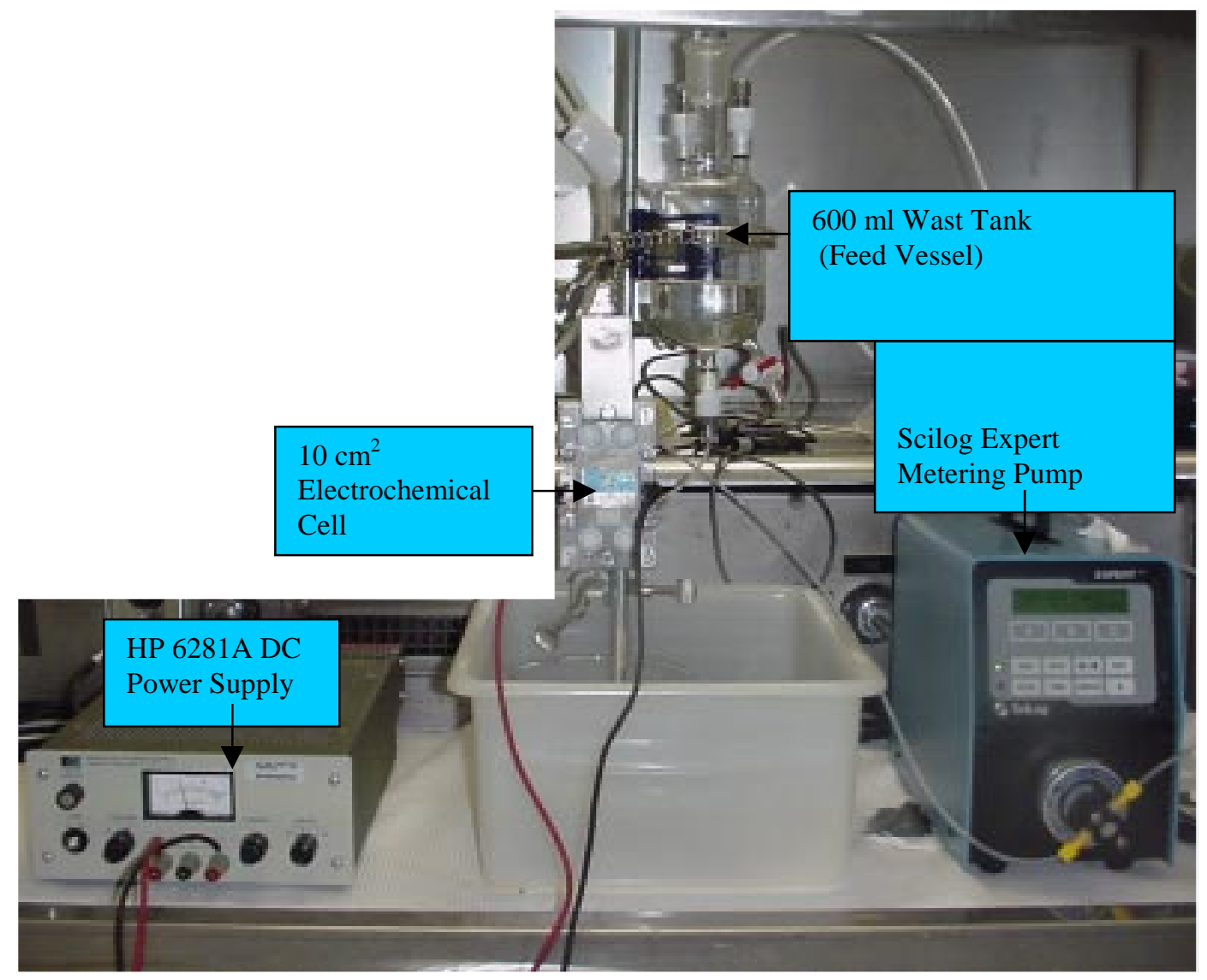

Figure 2- Photograph of Experimental Setup

Prior to testing we calibrated the feed vessel and feed pump. We operated the feed pump continuously at $100 \%$ speed and maximum stroke (4.5), which gave a flow of approximately $29 \mathrm{~mL} / \mathrm{min}$. This is equivalent to a flowrate of $\sim 15,000$ gallons per minute in a tank filled with 250,000 gallons of waste solution. We chose this flowrate to prevent the high gas generation "choking off" the flow from the electrolytic cell. The electrolytic cell works best with minimal gas inside. The accumulation of gas decreases the conductivity of the solution causing it to oscillate from high flow/high current to no flow/no current. Maintaining the maximum liquid flow to the cell eliminated this oscillation.

The plan for this testing featured two phases of testing. The first test phase evaluated nitrite and hydroxide production at two different current densities and two different electrode pairs. Table 1 lists the pertinent variables.

Table 1 - Phase 1 Experiments

\begin{tabular}{|c|c|c|c|}
\hline Experiment \# & Designation & Current Density & Cathode/Anode \\
\hline 1 & DL-NiNi1 & $0.1 \mathrm{amps} / \mathrm{cm}^{2}$ & Nickel/Nickel \\
\hline 2 & DL-NiNi2 & $0.2 \mathrm{amps} / \mathrm{cm}^{2}$ & Nickel/Nickel \\
\hline 3 & DL-NiPt1 & $0.1 \mathrm{amps} / \mathrm{cm}^{2}$ & Nickel/Platinum \\
\hline 4 & DL-NiPt2 & $0.2 \mathrm{amps} / \mathrm{cm}^{2}$ & Nickel/Platinum \\
\hline
\end{tabular}


Based on the results of Phase I of the testing, Phase II tests would evaluate alternative cathode/anode pairs and lower current densities to maximize the production of nitrite. Funding limits prevented performing any of the Phase II tests.

Table 2 - Phase 2 Experiments

\begin{tabular}{|c|l|l|l|}
\hline Run \# & Designation & Current Density & Cathode/Anode \\
\hline 5 & DL-NiNi3 & $0.01 \mathrm{mps} / \mathrm{cm}^{2}$ & Nickel/Nickel \\
\hline 6 & DL-NiPt3 & $0.01 \mathrm{mps} / \mathrm{cm}^{2}$ & Nickel/Platinum \\
\hline 7 & DL-NiPt2 & $0.01 \mathrm{amps} / \mathrm{cm}^{2}$ & Nickel/Other \\
\hline
\end{tabular}

The simulated waste solution for Phase I tests featured a simple salt solution comprised of sodium hydroxide, sodium nitrate and sodium nitrite. Table 3 provides the quantities of reagent grade chemical used to prepare the two batches of simulant prepared for the Phase I experiments.

Table 3 -Phase I Solution Composition

\begin{tabular}{|l|c|c|c|}
\hline & Batch 1 & Batch 2 & Target \\
\hline $\mathrm{NaNO}_{2}$ & $13.80 \mathrm{~g}$ & $1.724 \mathrm{~g}$ & $0.1 \mathrm{M}$ \\
\hline $\mathrm{NaNO}_{3}$ & $169.99 \mathrm{~g}$ & $21.246 \mathrm{~g}$ & $1.0 \mathrm{M}$ \\
\hline $\mathrm{NaOH}$ & $41.25 \mathrm{~g}$ & $1.724 \mathrm{~g}$ & $0.5 \mathrm{M}$ \\
\hline $\mathrm{DI}$ Water & $2 \mathrm{~L}$ & $0.250 \mathrm{~L}$ & \\
\hline
\end{tabular}

Personnel checked the electrolytic cell, pump and feed tank for leaks using deionized (DI) water prior to each experiment. After the leak check, they drained the water from the system and added $500 \mathrm{~mL}$ of salt solution to the feed vessel. The feed pump was turned on to circulate the solution through the electrolytic cell. After circulating the solution for 15 minutes we energized the power supply providing DC power to the electrochemical reactor. We operated the electrochemical reactor at an amperage of 1 or 2 amperes. Start time for each experiment represented the time power initiated to the cell. We operated the feed pump flow and power to the electrochemical cell for 8 hours each day. After 8 hours, we de-energized the power supply to the electrochemical cell followed by the power to the feed pump. Operation of the system continued for three additional days by starting the pump flow and electric power each day. At the completion of each experiment, we drained the feed tank of all liquid. We flushed the system by circulating $250 \mathrm{ml}$ of DI. We drained and flushed the DI water from the system.

We collected and analyzed liquid and vapor samples to measure the removal of nitrate and production of nitrite and hydroxide. Reactions 1-5 (not all of the possible electrolytic reactions) would lead to the production of $\mathrm{O}_{2}, \mathrm{~N}_{2}, \mathrm{OH}^{-}$and $\mathrm{NO}_{2}^{-}$. Electrolysis of water would lead to $\mathrm{H}_{2}$ and $\mathrm{O}_{2}$. Previous testing of the nitrate/nitrite destruction reactions 
identified $\mathrm{N}_{2}, \mathrm{NH}_{3}$ and $\mathrm{N}_{2} \mathrm{O}$ as possible reaction product. As a result, we sampled the feed tank before each run and every four hours during processing. We analyzed these samples using ion chromatography for nitrite and nitrate ion concentration and by titration for determine the hydroxide ion concentration. At the completion of each day we pulled and analyzed a gas sample for $\mathrm{N}_{2}, \mathrm{H}_{2}$ and $\mathrm{O}_{2}$ by gas chromatography. At the completion of each test, we pulled an additional gas sample and contacted the sample with a $0.01 \mathrm{M}$ sulfuric acid solution to trap any ammonia present. Ion chromatographic analysis provided the ammonium $\left(\mathrm{NH}_{4}{ }^{+}\right)$ion content.

Table 4 - Phase I Sample and Analytical Schedule

\begin{tabular}{|c|c|c|c|c|}
\hline Experiment & $\# 1$ & $\# 2$ & $\# 3$ & $\# 4$ \\
\hline Sample Size & $15 \mathrm{~mL}$ & $15 \mathrm{~mL}$ & $15 \mathrm{~mL}$ & $15 \mathrm{~mL}$ \\
\hline Sample Frequency & Every 4 hours & Every 4 hours & Every 4 hours & Every 4 hours \\
\hline Liquid/Gas & Liquid & Liquid & Liquid & Liquid \\
\hline $\begin{array}{l}\text { ADS Submission } \\
\text { ID }\end{array}$ & 200030325 & 200030397 & 200030461 & 200030491 \\
\hline Analyses & $\begin{array}{l}\text { Free } \mathrm{OH}^{-}, \\
\text {IC anions }\end{array}$ & $\begin{array}{l}\text { Free } \mathrm{OH}^{-}, \\
\text {IC anions }\end{array}$ & $\begin{array}{l}\text { Free } \mathrm{OH}^{-}, \\
\text {IC anions }\end{array}$ & $\begin{array}{l}\text { Free } \mathrm{OH}^{-}, \\
\text {IC anions }\end{array}$ \\
\hline Sample Size & $50 \mathrm{ml}$ & $50 \mathrm{ml}$ & $50 \mathrm{ml}$ & $50 \mathrm{ml}$ \\
\hline Sample Frequency & Once per run & Every 8 hours & Every 8 hours & Every 8 hours \\
\hline Liquid/Gas & Gas & Gas & Gas & Gas \\
\hline $\begin{array}{l}\text { ADS Submission } \\
\text { ID }\end{array}$ & 200030326 & 200030398 & 200030462 & 200030492 \\
\hline Analyses & IC Ammonium & IC Ammonium & IC Ammonium & IC Ammonium \\
\hline Sample Size & $50 \mathrm{~mL}$ & $50 \mathrm{~mL}$ & $50 \mathrm{~mL}$ & $50 \mathrm{~mL}$ \\
\hline Sample Frequency & Every 8 hours & Every 8 hours & Every 8 hours & Every 8 hours \\
\hline Liquid/Gas & Gas & Gas & Gas & Gas \\
\hline $\begin{array}{l}\text { ADS Submission } \\
\text { ID }\end{array}$ & 200030327 & 200030399 & 200030463 & 200030493 \\
\hline Analyses & $\mathrm{GC}\left(\mathrm{N}_{2}, \mathrm{O}_{2}, \mathrm{H}_{2}\right)$ & $\mathrm{GC}\left(\mathrm{N}_{2}, \mathrm{O}_{2}, \mathrm{H}_{2}\right)$ & $\mathrm{GC}\left(\mathrm{N}_{2}, \mathrm{O}_{2}, \mathrm{H}_{2}\right)$ & $\mathrm{GC}\left(\mathrm{N}_{2}, \mathrm{O}_{2}, \mathrm{H}_{2}\right)$ \\
\hline
\end{tabular}

\section{Results and Discussion}

The Phase I experiments (see Table 1) evaluated the affect of anode material and current density on the rate of nitrate removal and nitrite/hydroxide production. Figure 3 provides a graph of the free hydroxide profile for each of the four experiments. In all four experiments the hydroxide concentration increased with time indicating a net production of hydroxide in the system. Table 5 is a summary of a least squares fit of the data, forcing the $y$-intercept at $0.5 \mathrm{M}$, which is the initial hydroxide concentration.. The slope in each of these cases is the generation rate of free hydroxide in $\mathrm{mol} / \mathrm{L} / \mathrm{h}$. Also, the high correlation $\left(\mathrm{r}^{2}\right)$ value indicates the data is well fit by a linear equation.

The electrode combination featuring a nickel cathode and nickel anode (NiNi) produced the higher hydroxide production. This combination proved 1-5-1.7 times faster than the nickel cathode and platinum anode $(\mathrm{NiPt})$ combination. Note that doubling the current density virtually doubled the hydroxide ion generation (i.e., 1.9 times for the $\mathrm{NiNi}$ combination versus 1.7 times for the NiPt combination). 
Table 5 - Calculated Rate of Hydroxide Generation, mol/L/h

\begin{tabular}{|c|c|c|c|}
\hline Experiment & $\begin{array}{c}\text { Intercept } \\
\text { mol/L }\end{array}$ & $\begin{array}{c}\text { Slope } \\
\text { mol/L/h }\end{array}$ & $\mathrm{r}^{2}$ \\
\hline DL-NiNi1 & 0.5 & 0.0207 & 0.99 \\
\hline DL-NiNi2 & 0.5 & 0.0385 & 0.99 \\
\hline DL-NiPt1 & 0.5 & 0.0139 & 0.99 \\
\hline DL-NiPt2 & 0.5 & 0.0233 & 0.92 \\
\hline
\end{tabular}

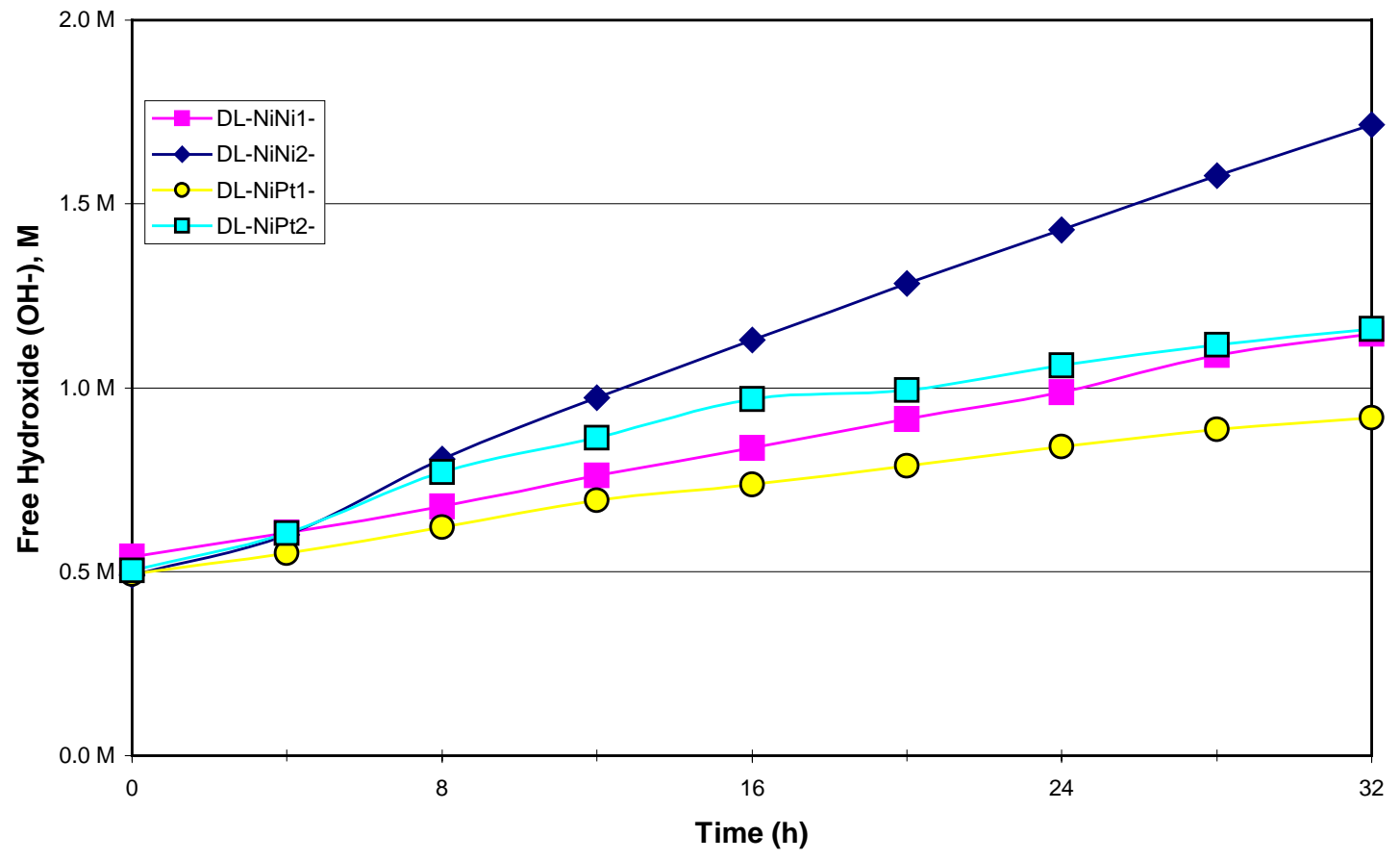

Figure 3 - Free Hydroxide (OH-) Trend

The rate of hydroxide generation observed in these tests is more than adequate to maintain a free hydroxide concentration in a HLW tank. The predominant mechanism for hydroxide depletion in HLW solutions is the absorption of atmospheric carbon dioxide and reaction with hydroxide to form carbonate and bicarbonate. The depletion rate depends on a number of factors including the atmospheric carbon dioxide concentration, the ventilation purge rate and the volume of waste in the storage tank. ${ }^{5,6}$ Depletion rates based on tank measurements range from 3E-04 to 3E-06 mole/(L-h) for waste volumes ranging from 10,000 to 1,000,000 gallons. The rates measured in these tests ranged from $1.4 \mathrm{E}-02$ to $3.8 \mathrm{E}-02$ mole/(L-h) indicating that the generation rate is more than adequate to meet the depletion rate and would steadily increase the hydroxide concentration in the bulk waste solution. 
Figures 4 and 5 provide graphs of the nitrite and nitrate concentration, respectively, for each of the four experiments. In all tests a net reduction occurred in the concentrations of both nitrite and nitrate. The nitrite concentration decreased linearly during the first 8 hours and then slowed. After about 16-20 hours, the nitrite concentration appeared to reach a steady-state concentration of between 0.020 and $0.035 \mathrm{M}$ for the remainder of the testing ( 32 hours). The nitrate concentration also decreased in each of the tests (see Figure 5). In two of the tests we measured a slightly higher nitrate concentration after 4 hours. Thereafter the nitrate concentration fell below the starting concentration. In general, the NiNi electrode combination provided a greater removal of nitrate than the $\mathrm{NiPt}$ combination. As observed with hydroxide, the rate of nitrate removal increased by a factor of two when the current density doubled. This trend with current density suggests no other electrode reactions compete with the reduction of nitrate and the production of hydroxide.



Figure 4 - Nitrite Trend $\left(\mathrm{NO}_{2}^{-}\right)$ 


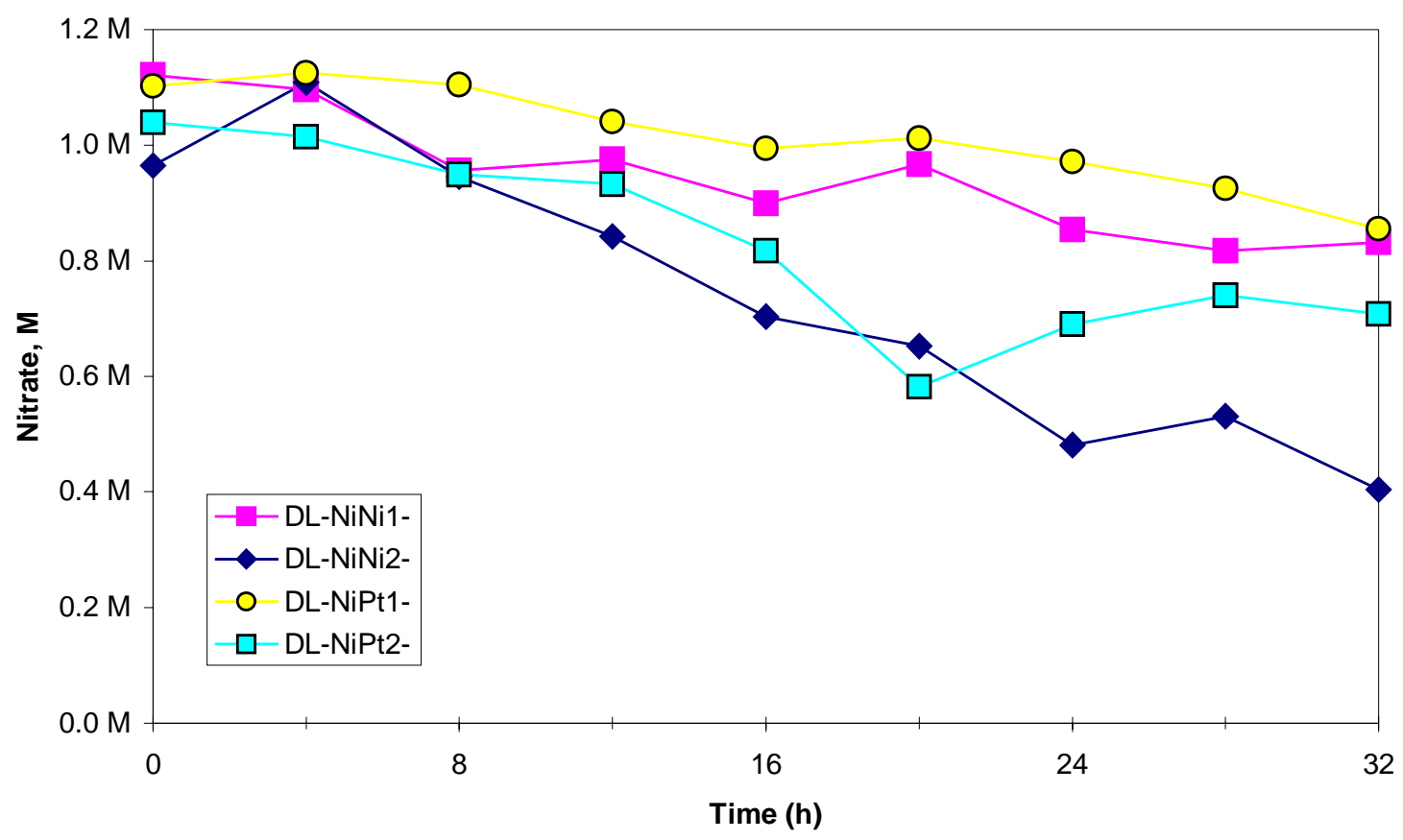

Figure 5 - Nitrate Trend $\left(\mathrm{NO}_{3}{ }^{-}\right)$

Under the conditions tested we observed an immediate decrease in nitrite concentration to a steady-state concentration of between 0.020 and $0.035 \mathrm{M}$. Thus we did not observe any indication that a nickel cathode will simultaneously produce hydroxide and nitrite in an undivided electrochemical cell. Lower current densities may decrease the nitrite reduction rate sufficiently to produce a higher steady-state concentration of nitrite. Alternatively, a different cathode material (e.g., Pt) may exhibit lower nitrite reduction kinetics resulting in the net production of nitrite in an undivided cell.

Table 6 provides the results of the gas analysis. A significant quantity of hydrogen was generated in each of the experiments. The hydrogen generation was highest in the two runs with the maximum power density. The electrolysis of water should lead to one mole of hydrogen and one-half mole of oxygen per mole of water. This could lead to a hydrogen concentration as high as $66.7 \%$ and an oxygen concentration of $33.3 \%$. We did attempt to quantify the total hydrogen or oxygen production (both concentration and total gas generation rates are needed for this determination) in this phase of testing. The gas analyses did indicate that more oxygen than nitrogen formed in most of the experiments. The low hydrogen concentration may reflect leakage of hydrogen through the septum preferentially relative to the other gases.

A small quantity of ammonia also formed during the tests. The ammonia production proved greater in the runs with the highest power density. We did not attempt was made to quantify the total amount of ammonia produced. 
Further testing should use a continuous purge with an internal standard coupled with a gas flowmeter and possibly an online analyzer to quantify the gas generation. This experimental method would provide a more accurate set of data to determine gas production rates including the possibility of flammable vapor mixtures of hydrogen.

Table 6-Analysis of Gas Samples

\begin{tabular}{|c|c|c|c|c|c|}
\hline $\begin{array}{c}\text { Gas Samples } \\
\text { Number }\end{array}$ & $\begin{array}{c}\text { ADS Sample } \\
\text { Number }\end{array}$ & $\begin{array}{c}\text { Hydrogen, } \\
\text { vol \% }\end{array}$ & $\begin{array}{l}\text { Oxygen, } \\
\text { vol \% }\end{array}$ & $\begin{array}{c}\text { Nitrogen, } \\
\text { vol \% }\end{array}$ & $\mathrm{NH}_{4}{ }^{+}$ \\
\hline DL-NiNi1-CG & 64310 & 16.02 & 83.98 & - & \\
\hline DL-NiNi1-EG & 64311 & 18.52 & 78.12 & 3.36 & \\
\hline DL-NiNi1-GG & 64312 & 22.18 & 76.79 & 1.04 & \\
\hline DL-NiNi1-IG & 64313 & 24.91 & 74.57 & 0.51 & \\
\hline DL-NiNi1-JL & & & & & $2 \mathrm{mg} / \mathrm{L}$ \\
\hline DL-NiNi2-CG & 64610 & 5.99 & 81.03 & 12.98 & \\
\hline DL-NiNi2-EG & 64611 & 19.46 & 79.64 & 0.90 & \\
\hline \multirow[t]{2}{*}{ DL-NiNi2-GG } & 64612 & 30.79 & 45.27 & 2.11 & \\
\hline & & 31.31 & 45.20 & 3.41 & \\
\hline \multirow[t]{2}{*}{ DL-NiNi2-IG } & 64613 & 34.90 & 49.93 & 0.57 & \\
\hline & & 35.24 & 49.62 & 0.74 & \\
\hline DL-NiNi2-TL & & & & & $33 \mathrm{mg} / \mathrm{L}$ \\
\hline \multirow{2}{*}{ DL-NiPt1-CG } & 65028 & 7.97 & 82.38 & 14.23 & \\
\hline & & 7.97 & 82.07 & 14.29 & \\
\hline \multirow{2}{*}{ DL-NiPt1-EG } & 65029 & 19.99 & 14.71 & 44.19 & \\
\hline & & 20.65 & 15.01 & 45.73 & \\
\hline \multirow{2}{*}{ DL-NiPt1-GG } & 65030 & 37.02 & 49.38 & 15.70 & \\
\hline & & 37.82 & 49.41 & 15.84 & \\
\hline \multirow{2}{*}{ DL-NiPt1-IG } & 65031 & 16.04 & 45.14 & 42.17 & \\
\hline & & 16.05 & 45.60 & 42.30 & \\
\hline DL-NiPt1-JL & & & & & $10 \mathrm{mg} / \mathrm{L}$ \\
\hline \multirow[t]{2}{*}{ DL-NiPt2-CG } & 65239 & 28.13 & 77.33 & 2.92 & \\
\hline & & 28.21 & 76.63 & 2.75 & \\
\hline \multirow[t]{2}{*}{ DL-NiPt2-EG } & 65240 & 29.62 & 29.62 & 12.82 & \\
\hline & & 50.42 & 47.52 & 1.89 & \\
\hline \multirow[t]{2}{*}{ DL-NiPt2-GG } & 65241 & 32.55 & 23.34 & 19.21 & \\
\hline & & 32.45 & 23.81 & 19.73 & \\
\hline
\end{tabular}

\section{Conclusions and Recommendations}

The use of a simple undivided electrolytic cell generated hydroxide, but not nitrite. The rate of hydroxide generation is more than adequate to maintain or increase hydroxide concentrations in HLW tanks due to depletion from atmospheric carbon dioxide absorption. Testing indicated consumption of both nitrate and nitrite in the undivided cell. The high hydrogen concentrations in the cell off-gas indicate that a portion of the electrical energy went into water electrolysis. 
We recommend future testing evaluate alternate cathode materials (e.g., platinum), current densities and cell configurations (e.g. divided cell) to increase nitrite generation. Also, we recommend testing to quantify gas generation rates. The gas generation rate data will aid development of a flammability strategy, if necessary, to maintain the gas concentration well below the lower flammable limits.

\section{Acknowledgments}

The authors thank Lin Thacker, Minnie Hightower and Dennis Lewis for their excellent work in constructing the testing apparatus and conducting the experiments. The authors also thank the following Analytical Development Section staff for their analysis of the liquid and gas samples in support of this testing program: Robert Ray, June Hart, Amy Ekechukwu, and Steve Crump. The authors thank Paul d'Entremont for helpful discussions relevant to tank deployment of this technology and the financial support of the SRTC Strategic R\&D program. 


\section{References}

1 "Electrochemical Treatment of Alkaline Nuclear Wastes," Innovative Technology Summary Report, DOE/EM-0560, January 2001.

2 "Electroreduction of Nitrate Ions in Concentrated Sodium Hydroxide Solutions at Lead, Zinc, Nickel, and Phthalocyanine-Modified Electrodes, " H. -L. Li, J. Q. Chambers, and D. T. Hobbs, Journal Applied Electrochemistry, 18, 454-458 (1988).

3 "Electrochemical Reduction of Nitrates and Nitrites in Alkaline Nuclear Waste Solutions," J. David Genders, Dan Hartsough, and D. T. Hobbs, J. Applied Electrochemistry, 26, 1-9 (1996).

4 “Electrolytic Denitration of Radioactive Savannah River Site Waste," Report WSRC-TR-95-0176, Savannah River Site, April 26, 1995.

${ }^{5}$ D. T. Hobbs and R. M. Wallace, "Hydroxide Depletion in Waste Storage Tanks by Reaction with Carbon Dioxide,” DPST-85-846, October 14, 1985.

${ }^{6}$ D. T. Hobbs, “Absorption of Carbon Dioxide in Waste Tanks,” DPST-87-596, September 3, 1987. 